\title{
Akademisyenler ve Öğretmenler Arasındaki İletişimin Hizmet Sürecindeki Öğretmen Eğitimine Yansımalarının İncelenmesi*
}

\section{Nesli Kala ${ }^{1}$ Arzu Kirman Bilgin ${ }^{2}$ Selcan Sungur Alhan ${ }^{3}$}

Type/Tür:

Research/Araştırma

Received/Geliş Tarihi: May 24/

24 Mayıs 2020

Accepted/Kabul Tarihi: March

22/ 22 Mart 2021

Page numbers/Sayfa No: 579-600

Corresponding

Author/Iletişimden Sorumlu

Yazar: nkala0702@gmail.com

\section{$\checkmark$ iThenticate}

This paper was checked for plagiarism using iThenticate during the preview process and before publication. / Bu çalışma ön inceleme sürecinde ve yayımlanmadan önce iThenticate yazılımı ile taranmıştır.

Copyright (C) 2017 by

Cumhuriyet University, Faculty of Education. All rights reserved.

\section{Öz}

Öğretmen adaylarını mesleğe hazırlayan akademisyenler ile adaylar arasındaki iletişim genellikle mezun olduktan sonra kopmaktadır. Bu iletişim eksikliği, hizmet sürecindeki öğretmen eğitimini ve öğrencilerin akademik başarısını etkilemektedir. $\mathrm{Bu}$ düşünceden hareketle mevcut araştırma, eğitim alanındaki akademisyen ve öğretmenler arasındaki ilişkinin hizmet sürecindeki öğretmen eğitimine yansımalarını incelemeyi ve bu alanlarda ortaya çıkan mevcut sorunlara çözüm önerileri geliştirmeyi amaçlamaktadır. Fenomenoloji yöntemi ile yürütülen araştırmaya fen bilimleri, sosyal bilimler, matematik ve Türkçe alanlarından hem öğretmenler hem de akademisyenler gönüllü olarak katılmışlardır. Her alandan ikişer öğretmen ve akademisyen olmak üzere toplam 16 katılımcının görüşlerine başvurulmuştur. Veriler, yarı yapılandırılmış sorulardan oluşan mülakatlar ile toplanmıştır. Bu amaçla, akademisyen ve öğretmenler için iki farklı yarı yapılandırılmış mülakat formu geliştirilmiştir. Elde edilen veriler, içerik analizine tabi tutulmuş olup betimsel olarak öğretmen ve akademisyen görüşlerine de bulgularda yer verilmiştir. Araştırma sonucunda öğretmen ve akademisyenler arasında yeterli iletişimin olmadığı, haftada 2-3 saat süresince akademisyenlerin okullara giderek öğretmenlerle iletişim kurması ve istedikleri konularda onlara hizmet vermesi gerektiği ortaya çıkarılmıştır. Bunun yanında, akademisyenlerin okullarda yapması gereken bazı faaliyetler konusunda farklı görüşlerde oldukları belirlenmiştir. Bu anlamda öğretmen görüşlerinin en fazla "öğrenme ortamlarının düzenlenmesi" temasında yoğunlaştığı ki burada da daha fazla "program değişimi" kodunda yoğunlaştığı sonucuna varılmıştır. Akademisyenlerin hem iletişim hem de güncel uygulamaları görmeleri açısından öğretmenleri öğretmen eğitimindeki bazı uygulamalı derslere davet etmeleri önerilmektedir.

Anahtar Kelimeler: Akademisyen, Akademik çalışma, İletişim, Hizmet Sürecindeki Öğretmen, Öğretmen Eğitimi

\section{Suggested APA Citation/Önerilen APA Atıf Biçimi: \\ Kala, N., Kirman-Bilgin, A. \& Sungur-Alhan, S. (2021). Akademisyenler ve öğretmenler arasındaki iletişimin hizmet sürecindeki öğretmen eğitimine yansımalarının incelenmesi. Cumhuriyet International Journal of Education, 10(2), 579-600. http://dx.doi.org/10.30703/cije.742093}

\footnotetext{
${ }^{1}$ Dr. Öğr. Üyesi, Kafkas Üniversitesi, Matematik ve Fen Bilimleri Eğitimi Bölümü, Kars/Türkiye Assist. Prof. Dr., Kafkas University, Maths and Science Education Department, Kars/Turkey e-mail: nkala0702@gmail.com ORCID ID: orcid.org/: 0000-0002-4608-708X

${ }^{2}$ Dr. Öğr. Üyesi, Kafkas Üniversitesi, Matematik ve Fen Bilimleri Eğitimi Bölümü, Kars/Türkiye Assist. Prof. Dr., Kafkas University, Maths and Science Education Department, Kars/Turkey e-mail: arzukirmanbilgin@gmail.com ORCID ID: orcid.org/ 0000-0002-5588-7353

${ }^{3}$ Dr. Öğr. Üyesi, Kafkas Üniversitesi, Matematik ve Fen Bilimleri Eğitimi Bölümü, Kars/Türkiye Assist. Prof. Dr., Kafkas University, Maths and Science Education Department, Kars/Turkey e-mail: sungurselcan@gmail.com ORCID ID: orcid.org/ : 0000-0002-7621-2961

*Bu araştırma, 2018-EB-82 proje numarası ile Kafkas Üniversitesi Bilimsel Araştırma Koordinatörlüğü tarafından desteklenmektedir.
} 


\title{
Examination of the Reflections of the Communication between Academicians and Teachers on the Training of In-service Teachers
}

\begin{abstract}
The communication between academicians who prepare the candidate teachers for this profession and the candidates is generally cut off after graduation. The objective of this study is to examine the impact of the communication between academicians in education faculties and the teachers on the training of in-service teachers and to develop solution suggestions for the issues that emerged in these areas. Phenomenology method was used in the study. Science Education, Mathematics Education, Social Sciences Education and Turkish Education were taken into consideration when determining the participants of the study on account of the fact that teachers and academicians in different disciplines may have different perspectives regarding the communication between academicians and teachers. This study has been conducted with total 16 participants, 2 teachers and 2 academicians from each department. The data were collected through interviews that consist of semi-structured questions. Two different semi-structured interview forms have been developed for this purpose including one for the teachers and one for the academicians. The obtained data were subjected to content analysis and the views of teachers and academicians were descriptively included in the findings. This study has shown that there is no communication between academicians and teachers, and academicians should go to schools and communicate with teachers for 2-3 hours a week. Moreover, the participants have different opinions on activities that the academicians should carry out at schools. In this regard, it was observed that teacher opinions focused mostly on the "arrangement of learning environments" theme and the "program change" code that is a part of this theme. It is recommended that academicians should invite teachers to some practice lessons in teacher education in terms of both communication and to see the current practices.
\end{abstract}

Keywords: Academician, Academic Study, Communication, In-Service Teachers, Teacher Training

\section{Giriş}

Öğretmen adayları ile onları mesleğe hazırlayan akademisyenler arasındaki iletişim, adayların atanarak çoğunlukla farklı şehirlerde mesleki yaşantılarına başlamaları, yeni ortam ve yeni yaşamlarına adaptasyonları gibi nedenlerle çoğunlukla mezun olduktan sonra kopmaktadır. Ülkemizde bu iletişimi sağlayan yollardan bir tanesi hizmet içi eğitim seminerleridir. Eğer hizmete atılan öğretmen, kendini geliştirmek istediğ konuyla ilgili bir mesleki eğitim almak isterse ve bu eğitimde akademisyenler görev almışsa akademisyen-öğretmen iletişimi kurmak için bir firsat doğmuş demektir. Finlandiya'da öğretmenlerin atanabilmeleri için yüksek lisans yapma zorunluluğu olduğundan bu iletişim süreci devam etmektedir (Eraslan, 2008). Japonya'da ise lisansüstü eğitime başlayan öğretmen ders vermeyi bırakır ve maaş almaya devam eder. Devlet bu teşvikle birlikte dolaylı olarak akademisyen-öğretmen ilişkisini kurmaya devam eder. Finlandiya, Japonya, Yeni Zelanda ve Güney Kore gibi ülkelerde atanan öğretmenler uzun süreli bir hizmet içi eğitim programına katılırlar ve bu eğitimlerin verildiği kurumlardan bir tanesi de üniversitelerdir (Abazaoğlu, 2014; Mete, 2013). Dolayısıyla öğrencilerin akademik başarılarının yüksek olduğu bu tür ülkelerde hizmet içi eğitim faaliyetleri aracılığıyla akademisyen-öğretmen iletişiminin sağlandığı söylenebilir. Ülkemizde ise öğrencilerin akademik başarılarını artırmak için yapılan araştırmalar incelendiğinde öğretmenlerin hizmet öncesi ve hizmet içi eğitimleri ile ilgili gerekli olan özellikler arasında okul idarecileri, uygulama 
öğretmenleri, uygulama öğretim üyeleri ve öğretmen adayları arasındaki sağlıklı iletişim süreci olduğu görülmektedir (Karasu-Avc1 ve Ünal-İbret, 2016). Fakat bu iletişim sürecinin, beklenen iş birliği içinde yürütülmediğine dair çalışmalar da mevcuttur (Azar, 2003; Dallmer, 2004; Gökçe ve Demirhan, 2005; Karasu-Avc1 ve Ünalİbret, 2016; Özkılıç, Bilgin ve Kartal, 2008; Sılay ve Gök, 2004).

Yüksek Öğretim Kurumu (YÖK) ile Milli Eğitim Bakanlığı (MEB) arasındaki iletişime yönelik başrol, akademisyenlere ve öğretmenlere düşmektedir. Akademisyenler ve öğretmenler daha çok öğretmen adaylarının okul deneyimi ve öğretmenlik uygulaması dersleri sayesinde iletişim kurmaktadırlar. Yapılan çalışmalar ise bu iletişim süreçlerinde önemli sorunların olduğunu ve bu sorunların giderilmesi için gözlemcilerin, değerlendirmelerini yapmak için bir araya gelebilecekleri fiziksel ortamların oluşturulmasının gerekliliğini (Yeşil ve Çalışkan, 2006) göstermektedir. Karakaya ve Brusseau (2015) ve Yalın-Uçar (2012), bu süreçlerin yürütebilmesi için üniversite ve okullar arasında yeterli iletişimin sağlanması gerektiğini fakat iki tarafın da bu konuda ilgisiz olduklarını belirlemişlerdir. Ünver (2003) ise öğretmenlik uygulaması dersi kapsamında öğretmenlerden ve akademisyenlerden oluşan bir komisyonun kurulmasının ve her hafta fakültelerde yapılan teorik derslere öğretmenlerin de katılarak, kendi gözlem ve değerlendirmelerini yapmalarının, üniversitelerde yapılan çalışmalardan haberdar olmalarının ve ders planlarının oluşturulmasında da etkin rol oynamalarının öğretmen adaylarının mesleki becerilerini artırma açısından faydalı olacağını tespit etmiştir. Bilgin-Aksu (2004) araştırmasında öğretmenlerin, akademisyenleri okullarda daha fazla görmek istediklerini, fakülte ve okullar arasında ders programı ortaklı̆̆ının dikkate alınması gerektiğini ortaya çıkarmıştır. Öğretmen adayları, adaylıkları boyunca akademisyenler tarafından yetiştirilirler. Dolayısıyla hizmet sürecine başladıkları zaman ilgili gelişmeleri takip edebilmek için akademisyenlerle iletişime geçmek istemeleri ve iş birliği yolu ile ihtiyaçlarını karşılamak istemeleri doğal bir süreçtir. Fakat bu ihtiyacın nasıl karşılanması gerektiği merak konusudur. Çünkü her öğretmenin ihtiyac1, hitap ettiği öğrenci kitlelerinin ön öğrenmelerine, okulun bulunduğu sosyo-kültürel yapının farklılığına, okulun fiziki şartlarına, idari yapının farklılığına göre değişebilir. Yapılan çalışmalar öğretmenlerin daha çok bireyselleştirilmiş eğitim programı, eğitim teknolojileri ve materyal tasarlama, özel eğitim, eğitimde çağdaş yönelimler, alan bilgisi, öğretim programlarının tanıtımı, sınıf yönetimi, ölçme ve değerlendirme gibi konularda akademisyen desteğine ihtiyaç duyduklarını göstermektedir (Kirman-Bilgin, Kala-Aydın ve Sungur-Alhan, 2017; Sıcak ve Parmaksız, 2016). Bununla birlikte, öğretmenler istediği anlık ihtiyaçları karşılamak için uygun hizmet içi eğitim seminerlerine ulaşamayabilir veya istediği eğitime; ulaşım, ders yoğunluğu, ailevi sebeplerden dolayı katılamayabilirler (Ekinci ve Yıldırım, 2009; Gökdere ve Çepni, 2004; Gönen ve Kocakaya, 2006; Kirman-Bilgin, Kala-Aydın ve Sungur-Alhan, 2017; Kala, Sungur-Alhan ve Kirman-Bilgin ,2019). Finlandiya, Japonya, Yeni Zelanda ve Güney Kore gibi öğrencilerin akademik başarılarının yüksek olduğu ülkelerde hizmet içi eğitim programlarının okul merkezli yapılması da öğretmenlerin bireysel ihtiyaçlarına göre bu eğitimlerin verildiğinin bir göstergesi sayılabilir (Mete, 2013). Dolayısıyla ülkemizde mesleki gelişim süreçleri açısından, hizmet öncesi ve hizmet sürecindeki etkin rolü olan öğretmenlerin ve akademisyenlerin aralarındaki iletişimin nasıl yürütülmesi gerektiğine yönelik 
görüşleri merak konusudur. Aynı zamanda bu iletişim sürecinin öğretmenlerin bireysel ihtiyaçlarını karşılamak için nasıl yapılandırılması gerektiği de araştırılması gereken bir husustur. Bu iletişim sürecinin sağlanmasının temel sebebinin öğrencilerin akademik başarılarını artırmak olduğu düşünüldüğünde, araştırma sonuçlarının hem alan yazına hem de hizmet sürecindeki öğretmen eğitimi süreçlerine önemli katkılar sağlayacağı düşünülmektedir.

\section{Araştırmanın Amacı}

Mevcut araştırma, eğitim alanındaki akademisyen ve öğretmenler arasındaki iletişimin hizmet sürecindeki öğretmen eğitimine yansımalarını incelemeyi ve bu alanlarda ortaya çıkan mevcut sorunlara çözüm önerileri geliştirmeyi amaçlamaktadır. Araştırmanın amacı kapsamında aşağıda belirtilen araştırma sorularına yanıt aranmıştır:

1) Akademisyenlerin ve öğretmenlerin, hizmet sürecindeki öğretmen eğitimi ile ilgili kurdukları iletişim süreçleri nasıldır?

2) Öğretmenlerin mevcut bazı sorunlarını çözmek için akademisyenlerin okulları ziyaret etmesi ile ilgili görüşleri nelerdir?

3) Öğretmenlerin, okullarını ziyaret edecek akademisyen prototipi ile ilgili beklentileri nelerdir?

\section{Araştırma Deseni}

\section{Yöntem}

Mevcut çalışmada, akademisyenler ve öğretmenler arasındaki iletişimin görev yapmakta olan öğretmenlerin mesleki eğitimini ve akademisyenlerin çalışma süreçlerini nasıl etkilediğine dair düşünceler ve yaşanmışlıklar araştırılmaya çalışılmıştır. Dolayısıyla araştırma, nitel araştırma desenlerinden olgubilim (fenomenoloji) ile yürütülmüştür. Günlük yaşantımızda çeşitli şekillerde karşılaştı̆̆ımız olguları araştırmayı amaçlayan çalışmalar için fenomenoloji uygun bir araştırma yöntemidir (Yıldırım ve Şimşek, 2006). Johnson ve Christensen (2012)'e göre fenomenolojik araştırmanın amacı, araştırmanın katılımcılarının kendi deneyimleriyle yapılandırdıkları kişisel anlamları ortaya çıkarmak ve onların yaşam dünyalarıyla ilgili bir bakış açısı ortaya koymaktır. Bu araştırmada ise öğretmenler ve akademisyenlerin öznel deneyimlerine dayanarak bu iki grup arasındaki iletişimin belirlenmesi amacıyla görüşmeler yürütülmüştür.

\section{Katilımcilar}

Bu araştırma, 8 öğretim üyesi ve 8 ortaokul öğretmeninin katılımıyla yürütülmüştür. Katılımcılar, maksimum çeşitlilik örneklemesine göre seçilmiştir. Bu örneklemenin seçilmesindeki amaç, tüm durumların bir veya daha fazla boyutuyla araştırmaya dahil edilmesine olanak tanımasıdır (Johnson ve Christensen, 2012). Dolayısıyla bu örnekleme yöntemi ile araştırma mümkün olduğunca farklı boyutlarıyla ele alınabilir ve ortak noktalar belirlenebilir. Araştırma, öğretmenler ve akademisyenler arasındaki iletişimin belirlenmesine odaklandığı için hangi branşların dahil edileceği önemli bir durumdur. MEB'in atama yaptığ1 alan sayısının 50'nin üzerinde olduğu ve herhangi bir branş seçildiğinde bu branşa öğretmen yetiştiren akademisyenlerin de dahil edilmesi durumda hem katılımcı sayısının çok fazla olması hem de araştırmanın yürütüldüğü üniversitede tüm alanlar bulunmamasından dolayı araştırma ortaokula 
öğretmen yetiştiren bölümlerle sınırlandırılmıştır. Ayrıca araştırmanın yapıldı ğı üniversitede müzik, resim vb. bazı alanlarda öğretim üyesi bulunmadığı için araştırma, dört alanla sınırlandırılmıştır. Öğretim üyeleri, Türkiye'de bulunan bir devlet üniversitesinin eğitim fakültesindeki Fen Bilimleri, Matematik, Sosyal Bilgiler ve Türkçe Eğitimi Ana Bilim Dallarında görev yapmakta olan 2'şer akademisyenden oluşmaktadır. Öğretmen katılımı ise ilgili üniversitenin bulunduğu ilin milli eğitim müdürlüğüne bağlı devlet ortaokullarda Fen Bilimleri, Matematik, Sosyal Bilgiler ve Türkçe öğretmeni olarak görev yapan 1 kıdemsiz (0-2 yıl) ve 1 kıdemli olmak üzere (10 yıl ve üstü) toplam 2'şer öğretmenin gönüllü olmasıyla sağlanmıştır. Kodlama yapılırken kıdemsiz öğretmenler 1, kıdemliler 2 şeklinde kodlanmıştır. Burada branş ve kıdem bazında bir analiz yapılarak görüşlerin ortaya konulması hedeflenmemiş sadece örneklemede maksimum çeşitliliğin sağlanması hedeflenmiştir. Katılımcı öğretmen seçiminde eğitim fakültesinin belirtilen branşından mezun olma durumuna, akademisyen seçiminde ise ilgili ana bilim dalında doktorasını yapmış olma şartına dikkat edilmiştir. Araştırmaya katılan öğretmen ve akademisyenlere ait demografik bilgiler ve analizde kullanılan kısaltma (kod) aşağıdaki gibidir.

Tablo 1

Araştırmaya Katılan Öğretmen ve Akademisyenlere Ait Demografik Bilgiler

\begin{tabular}{|c|c|c|c|c|c|c|c|}
\hline \multicolumn{5}{|c|}{ Öğretmenlere Ait Bilgiler } & \multicolumn{3}{|c|}{ Akademisyenlere Ait Bilgiler } \\
\hline Branş & $\begin{array}{l}\text { Kidem } \\
\left(Y_{11}\right)\end{array}$ & $\begin{array}{l}\text { Cinsi } \\
\text { yet }\end{array}$ & $\begin{array}{c}\text { Lisansüstü Eğitim } \\
\text { Alma }\end{array}$ & Kodu & $\begin{array}{l}\text { Ana Bilim } \\
\text { Dalı }\end{array}$ & $\begin{array}{c}\text { Cinsiy } \\
\text { et }\end{array}$ & Kodu \\
\hline $\begin{array}{c}\text { Fen } \\
\text { Bilimleri }\end{array}$ & $\begin{array}{l}\text { Kidemsiz } \\
(2 \text { Yil) }\end{array}$ & Erkek & $\begin{array}{c}\text { Fen Bilimleri Eğitimi } \\
\text { (Yüksek Lisans) }\end{array}$ & ÖF1 & $\begin{array}{c}\text { Fen Bilimleri } \\
\text { Eğitimi }\end{array}$ & Erkek & AF1 \\
\hline $\begin{array}{c}\text { Fen } \\
\text { Bilimleri }\end{array}$ & $\begin{array}{l}\text { Kidemli } \\
(11 \text { Yil) }\end{array}$ & Kadın & $\begin{array}{c}\text { Fen Bilimleri Eğitimi } \\
\text { (Yüksek Lisans) }\end{array}$ & ÖF2 & $\begin{array}{c}\text { Fen Bilimleri } \\
\text { Eğitimi }\end{array}$ & Kadın & AF2 \\
\hline Matematik & $\begin{array}{l}\text { Kidemsiz } \\
\text { (Yeni } \\
\text { atama) }\end{array}$ & Kadın & - & ÖM1 & $\begin{array}{l}\text { Matematik } \\
\text { Eğitimi }\end{array}$ & Kadın & AM1 \\
\hline Matematik & $\begin{array}{l}\text { Kidemli } \\
(12 \text { Y1l) }\end{array}$ & Erkek & - & ÖM2 & $\begin{array}{l}\text { Matematik } \\
\text { Eğitimi }\end{array}$ & Kadın & AM2 \\
\hline $\begin{array}{c}\text { Sosyal } \\
\text { Bilimler }\end{array}$ & $\begin{array}{l}\text { Kidemsiz } \\
\text { (2 Yil) }\end{array}$ & Kadın & - & ÖS1 & $\begin{array}{c}\text { Sosyal } \\
\text { Bilimler } \\
\text { Eğitimi }\end{array}$ & Erkek & AS1 \\
\hline $\begin{array}{c}\text { Sosyal } \\
\text { Bilimler }\end{array}$ & $\begin{array}{l}\text { Kidemli } \\
(18 \text { Y } 11)\end{array}$ & Kadın & - & ÖS2 & $\begin{array}{c}\text { Sosyal } \\
\text { Bilimler } \\
\text { Eğitimi }\end{array}$ & Erkek & AS2 \\
\hline Türkçe & $\begin{array}{l}\text { Kidemsiz } \\
(1 \text { Yil })\end{array}$ & Erkek & - & ÖT1 & $\begin{array}{l}\text { Türkçe } \\
\text { Eğitimi }\end{array}$ & Kadın & AT1 \\
\hline Türkçe & $\begin{array}{l}\text { Kidemli } \\
\left(11 Y_{11}\right)\end{array}$ & Kadın & - & ÖT2 & $\begin{array}{l}\text { Türkçe } \\
\text { Eğitimi }\end{array}$ & Kadın & AT2 \\
\hline
\end{tabular}

\section{Veri Toplama Araçları}

Araştırmada veriler, yarı yapılandırılmış sorulardan oluşan mülakat formu vasıtasıyla toplanmıştır. Katılımcılar öğretmen ve akademisyenlerden oluştuğu için iki farklı mülakat formu geliştirilmiştir. Geliştirilen formda yer alan sorular kapsam geçerliği açısından üç alan uzmanına inceletilmiş, öneriler doğrultusunda yapılandırılarak 
kullanılmıştır. Mülakat formunda yer alan yarı yapılandırılmış sorular Tablo 2'de sunulmaktadir.

Tablo 2

Öğretmenlere ve Akademisyenlere Yöneltilen Mülakat Soruları

\begin{tabular}{|c|c|}
\hline Öğretmenlere yöneltilen sorular & Akademisyenlere yöneltilen sorular \\
\hline Üniversitedeki alanınızdaki hocalar - & Hizmet sürecindeki \\
\hline $\begin{array}{l}\text { örneğin matematik eğitimcisi vb.- okulunuzu } \\
\text { zivaret ettiklerinde ne hissedivorsunuz? }\end{array}$ & $\begin{array}{l}\text { eğitimine yönelik akademisyenlerle öğretmenler } \\
\text { arasındaki iletisimi nasıl buluyorsunuz? Nasıl }\end{array}$ \\
\hline 2) Akademisyenlerle $\quad$ o $\quad$ alandaki & olmalı? \\
\hline öğretmenler arasındaki diyaloğu nasıl & 2) Akademisyen öğretmen iletişimini \\
\hline buluyorsunuz? Yeterince irtibat halindeler mi? & geliştirmek için akademisyenlerin okullara gidip \\
\hline Sizce nasıl olmalı? & öğretmenlere rehberlik etmesi hakkında ne \\
\hline Üniversitedeki alanınızdaki hocalar sizce & düşünüyorsunuz? \\
\hline okulu daha sık ziyaret etmeliler mi? Neden? & Okullara rahatlıkla gidip öğretmenlerle \\
\hline Bu ziyaretin kapsamı ne olmalıdır? & ya da bir okul yöneticisi ile bir eğitim problemi \\
\hline Geldiklerinde nasıl davranmalılar? & uz? Neden? \\
\hline 6) Akademisyenler ne kadar sıklıkla okulu & 4) Sizce akademisyenler okulları ne kadar \\
\hline \multirow[t]{2}{*}{ ziyaret etmeliler? } & siklıkla ziyaret etmeliler? \\
\hline & Bu ziyaretin kapsamı ne olmalıdır? \\
\hline
\end{tabular}

\section{Verilerin Analizi}

Öğretmen ve akademisyen mülakatlarından elde edilen veriler içerik analizine tabi tutulmuştur. Analizin güvenirliğini sağlamak için verilerin \%25'i (2 akademisyen, 2 öğrenmen mülakatı) iki kodlayıcı tarafından kodlanarak kodlayıcı güvenirliğine bakılmıştır. Yapılan analize göre ilk kodlamada kodlayıcılar arasındaki uyum \%79 olarak bulunmuştur (Miles ve Huberman, 1994). Bu süreçten sonra iki araştırmacı bir araya gelerek yapılan kodlama ve oluşturulan kodlar konusunda tartışarak görüş birliği sağlanmıştır. Gerekli güvenirlik oranına ulaşıldığı için geri kalan \%75'lik veri tek bir araştırmacı tarafından kodlanmıştır. Kodlamadan sonra oluşturulan temalar, tüm araştırmacılar arasında yapılan tartışmalarla son hali verilmiştir. İçerik analizi sonucunda elde edilen kod ve temalar bulgular içerisinde yer verilmiştir. Öğretmen mülakatları ortalama 20-30 dakika, akademisyen mülakatları ise 30-55 dakika sürmüştür. Araştırmaya katılan öğretmen ve akademisyenlerin görüşleri sunulurken uzmanlık alanları da göz önüne alınıp, kodlanarak görüşleri belirtilmiştir. Öğretmen ve akademisyenlerin kodları Tablo 1'de görülmektedir.

\section{Bulgular}

Araştırmanın amacı çerçevesinde yapılan mülakatlardan elde edilen veriler alt araştırma sorularına göre sunulmaktadır.

\section{Araştırmanın Birinci Alt Araştırma Sorusundan Elde Edilen Bulgular}

Akademisyenler ve öğretmenlerin, hizmet sürecindeki öğretmen eğitimi ile ilgili kurdukları iletişim süreçleri nasıldır? şeklindeki birinci alt araştırma sorusu ile ilgili bulgular Tablo 3 'teki gibidir. 
Tablo 3

Öğretmen ve Akademisyenlerin, Hizmet Sürecindeki Öğretmen Ĕ̆itimi ile İlgili Kurdukları İletişim Süreçlerine Yönelik Elde Edilen Bulgular

\begin{tabular}{|c|c|c|c|c|c|}
\hline & \multicolumn{2}{|l|}{ Mevcut durum } & \multicolumn{3}{|l|}{ Beklenti } \\
\hline & Sınırlı İletişim & İletişim yok & $\begin{array}{l}\text { İletişim } \\
\text { İyileştirilmeli }\end{array}$ & $\begin{array}{l}\text { Sinırsız } \\
\text { iletişim } \\
\text { kurulabilmeli }\end{array}$ & $\begin{array}{l}\text { İşs birliği } \\
\text { şeklinde } \\
\text { olmalı }\end{array}$ \\
\hline Öğretmen & $\begin{array}{l}\text { ÖF1, ÖS1, ÖF2, } \\
\text { ÖT2 }\end{array}$ & $\begin{array}{l}\text { ÖM1, ÖM2, } \\
\text { ÖS2, ÖT1 }\end{array}$ & $\begin{array}{l}\text { ÖF1, ÖF2, ÖM1, } \\
\text { ÖM2, ÖS1, ÖT1 }\end{array}$ & ÖS1 & $\begin{array}{l}\text { ÖF2, ÖS1, } \\
\text { ÖT1, ÖT2 }\end{array}$ \\
\hline Akademisyen & $\begin{array}{l}\text { AT1, AM1, } \\
\text { AM2, AS2, AF1, } \\
\text { AF2 }\end{array}$ & AS1, AT2 & $\begin{array}{lll}\text { AT1, } & \text { AM1, } & \text { AS1, } \\
\text { AM2, } & \text { AS2, } & \text { AT2, } \\
\text { AF1, AF2 } & \end{array}$ & - & AS1, AF2 \\
\hline
\end{tabular}

Tablo 3 incelendiğinde katılımcı akademisyen ve öğretmenlerin tümünün bu iki grup arasında yeterli iletişimin olmadığını düşündükleri hatta bazı katılımcıların akademisyen ve öğretmenler arasında hiç iletişim olmadığını belirttikleri görülmektedir. Bununla birlikte katılımcıların tamamına yakınının akademisyen ve öğretmenler arasındaki iletişimin iyileştirilmesi gerektiğini, bazı katılımcıların ise bu iletişimin iş birliği şeklinde kurulması gerektiğini ifade ettikleri dikkat çekmektedir. Bu konuda ÖF1 kodlu öğretmenin,

"Burada hocalarla görüşme şansım var. Bir şekilde görüş alış verişi yapabilirim, zorlandığım noktada soru sorabilirim ya da bunu çocuklara nasıl verebilirim diye bir konuşma geçebilir hocalarımla aramızda ama diğer hocalarm (öğretmenlerin)... ya da bunun için illa yüksek lisans mi yapması gerekli? ya da bir öğretmenin üniversiteyi ziyaret etmesi için ya da üniversitede bir toplantı yapması için..." şeklindeki cümlelerinden yüksek lisans yaptığ için üniversitedeki öğretim üyelerine ulaşma şansını yakaladığ1 görülmektedir. ÖT2 kodlu öğretmen ise görüşlerini,

"Paslaşmamız lazım. Öğretmenler de fakülteye gelip öğrenci tepkilerini paylaşmall, akademisyenler de okula gelip problemleri görüp çözüm getirmeli, buna göre aday yetiştirmeli." cümleleriyle dile getirmektedir. Katılımcı akademisyen ve öğretmenlere hem bu iki grup arasındaki iletişimi güçlendirmek hem de hizmet sürecindeki öğretmenlere katkı yapmak için akademisyenlerin okulları ziyaret etmesi konusunda sorular yöneltilmiştir. Bu konu ile ilgili katılımcı akademisyen ve öğretmenlerin görüşleri Tablo 4'de görülmektedir.

\section{Araştırmanın İkinci Alt Araştırma Sorusundan Elde Edilen Bulgular}

"Öğretmenlerin mevcut bazı sorunlarını çözmek için akademisyenlerin okulları ziyaret etmesi ile ilgili görüşleri nelerdir?" şeklindeki ikinci alt araştırma sorusu ile ilgili bulgular Tablo 4'de sunulmaktadır. 
Tablo 4

Akademisyenlerin Okulları Ziyaret Etmesi ile İlgili Öğretmen ve Akademisyen Görüşleri

\begin{tabular}{|c|c|c|c|c|c|c|c|}
\hline & \multicolumn{2}{|c|}{ Genel Düşünce } & \multicolumn{5}{|c|}{ Ne kadar sıklıkla okullara gidilmeli? } \\
\hline & $\begin{array}{l}\text { Kesinlikle } \\
\text { gidilmeli }\end{array}$ & Gidilebilir & $\begin{array}{l}\text { Haftada } \\
1 \text { saat }\end{array}$ & $\begin{array}{l}\text { Haftada 2-3 } \\
\text { saat }\end{array}$ & $\begin{array}{l}\text { Haftada } \\
\text { saat } \\
\text { fazlasi }\end{array}$ & $\begin{array}{r}4 \\
\text { ve }\end{array}$ & $\begin{array}{l}\text { Süreç } \\
\text { karş1liklı } \\
\text { planlanmalı }\end{array}$ \\
\hline Öğretmen & $\begin{array}{ll}\text { ÖF1, } & \text { ÖT2, } \\
\text { ÖM2, } & \text { ÖS1, } \\
\text { ÖT2 }\end{array}$ & $\begin{array}{l}\text { ÖM1, ÖF2, } \\
\text { ÖS2 }\end{array}$ & ÖF2, & $\begin{array}{ll}\text { ÖF1, ÖM1, } \\
\text { ÖM2, ÖS1, } \\
\text { ÖT2 }\end{array}$ & ÖT1 & & ÖT1, ÖS1 \\
\hline Akademisyen & $\begin{array}{l}\text { AT1, } \\
\text { AM1, } \\
\text { AM2, } \\
\text { AS2, } \\
\text { AT2, } \\
\text { AF2 }\end{array}$ & - & AF1 & $\begin{array}{ll}\text { AT1, } & \text { AT2, } \\
\text { AS1, } & \text { AS2, } \\
\text { AM1 } & \end{array}$ & AM2 & & AF2 \\
\hline
\end{tabular}

Tablo 4 incelendiğinde katılımcı öğretmen ve akademisyenlerin tamamına yakını akademisyenlerin okullara gitmesi gerektiğini belirtmişlerdir. AS1 kodlu öğretim üyesi bu konudaki düşüncelerini,

"Sonuçta o öğretmenler bizim memleketimizin insanın yetiştiriyor, Türkiye Cumhuriyeti'nde yaşayan insanlarn yetiştiriyor. Ne kadar iyi eğitim verirsek o kadar faydalı olur ülkemize, bizim işimiz bu yani, işten de kaçmayız." cümleleriyle ifade etmiştir.

Alandaki akademisyenler okullara gitmesi gerektiği konusunda katılımcilar arasında büyük oranda fikir birliği olmasına rağmen "ne kadar sürede bir okula gitmeliler?" sorusuna verilen yanıtlarda çeşitlilik olduğu tablodan görülmektedir. Bu konuda ÖM1 kodlu öğretmen düşüncelerini,

"Haftada 2 saat yeterli olabilir. Daha fazlası birine bağımlı hale getirebilir. O olmadan bir şeyler üretemeyebilirsiniz. Çünkü ona güveneceksin nasıl olsa o var diye ondan bekleyeceksin." şeklinde ifade etmiştir. ÖS1 kodlu öğretmen ise düşüncelerini,

"Dersimde çok fazla birisinin bulunmasın istemem. Haftada birkaç saat olabilir. Önerilerde bulunur, kitaplar tavsiye edebilir. İstediğim anda ulaşabilecek bir danışmanım olsun isterim. Istediğim şeyi istediğim zaman sorabilmeyi ve rahat bir iletişim isterim. Planl bir süreç olursa iyi olur" şeklinde belirtmektedir.

Akademisyen ve öğretmen iletişimini artırmak için akademisyenlerin okulları ziyaret etmesinde önemli hususlardan biri de bu süreçte akademisyenlerin karşılaşabileceği sorunlardır. Bu konudaki akademisyen ve öğretmen görüşleri Tablo 5 'da sunulmaktadir.

Tablo 5

Okulların Ziyareti Sürecinde Akademisyenlerin Karşılaşabileceği Sorunlar Hakkında Öğretmen ve Akademisyen Görüşleri

\begin{tabular}{lllllll}
\hline & $\begin{array}{l}\text { MEB } \\
\text { prosedürleri }\end{array}$ & $\begin{array}{l}\text { Müdür } \\
\text { engeli }\end{array}$ & $\begin{array}{l}\text { İkili } \\
\text { ilişkiler }\end{array}$ & $\begin{array}{l}\text { Akademisyen } \\
\text { Yoğunluğu }\end{array}$ & $\begin{array}{l}\text { Öğretmen } \\
\text { Yoğunluğu }\end{array}$ & $\begin{array}{l}\text { Corun } \\
\text { Ç1kmaz }\end{array}$ \\
\hline Öğretmen & - & - & - & ÖM2,ÖF2 & ÖS1,ÖT1 & $\begin{array}{l}\text { ÖM1,ÖS2, } \\
\text { ÖT2,ÖF1 }\end{array}$ \\
\hline Akademisyen & $\begin{array}{l}\text { AT1,AS1,AM1, } \\
\text { AM2,AF1 }\end{array}$ & $\begin{array}{l}\text { AF1,AF2, } \\
\text { AS2,AT2 }\end{array}$ & $\begin{array}{l}\text { AM2,AF2, } \\
\text { AT2 }\end{array}$ & AT2 & AM2 & - \\
& & & & & \\
\hline
\end{tabular}


Tablo 5 incelendiğinde akademisyenlerin okullara gittiklerinde karşılaştığ genel sorunun MEB'in prosedürleri olduğu görülmektedir. Örneğin, bu konuda AM2 kodlu öğretim üyesi düşüncelerini,

"Siz eğer resmi bir prosedürle gitmemişseniz, o şahsin günlük rutinini etkileyecek bir şeyi insanlar istemeyebiliyor. Bunun faydastna olsun olmasın, onun günlük bir rutini var, resmi olarak buna zorunlu değilse ya da siz resmi bir kanalla gitmemişseniz ben bunun negatif bir dönüt olacă̆ın düşünüyorum. Çünkü Milli Eğitim'de her şey rutindir, her şeyin belli bir prosedürü vardır" şeklinde ifade etmiştir.

Akademisyenlerin okulları ziyaret etmesi konusunda hem öğretmenlerin hem de akademisyenlerin büyük oranda hemfikir oldukları elde edilen verilerin analizinden görülmektedir. Akademisyenlerin okulları ziyaret etme gereksinimleri ile ilgili öğretmen ve akademisyen görüşleri ise Tablo 6'deki gibidir.

Tablo 6

Akademisyenlerin Okulları Ziyaret Etme Gereksinimleri ile İlgili Öğretmen ve Akademisyen Görüşleri

\begin{tabular}{|c|c|c|c|}
\hline Tema & Kod & Öğretmen & Akademisyen \\
\hline \multirow{4}{*}{ Genel Sorunlar } & Kazanılması zor konular & ÖF1,ÖM2,ÖS1,ÖT2 & AF1, AT2 \\
\hline & Güncel bilgiler & ÖF1, ÖF2 & AT1, AM2, AT2 \\
\hline & Problemlerin yerinde tespiti & ÖT2, ÖF2 & AT1, AF1 \\
\hline & $\begin{array}{l}\text { Hizmet Öncesi Öğretmen } \\
\text { Eğitimi }\end{array}$ & ÖS1, ÖS2, ÖT2 & AT1 \\
\hline \multirow{3}{*}{$\begin{array}{l}\text { Öğrencilere İliş̧kin } \\
\text { Sorunlar }\end{array}$} & $\begin{array}{l}\begin{array}{l}\text { Davranış } \\
\text { öğrenciler }\end{array} \\
\text { bozukluğu }\end{array}$ & ÖF2 & - \\
\hline & Farklı yetenekteki öğrenciler & ÖT2 & - \\
\hline & Öğrenme güçlüğü & $\begin{array}{l}\text { ÖF1, ÖF2, ÖM1, } \\
\text { ÖT2 }\end{array}$ & - \\
\hline
\end{tabular}

Araştırmadan elde edilen verilerin analizinden akademisyenlerin okullara gitmesi konusunda gerek öğretmenler gerekse akademisyenler arasında fikir birliği olmasına rağmen akademisyenlerin okullarda oynayacağı rolle ilgili farklı görüşlerin olduğu görülmektedir (Tablo 6). Örneklemdeki ÖF1, ÖM2, ÖS1, ÖT2 kodlu öğretmenler ve AF1, AT2 kodlu akademisyenler, akademisyenlerin okullara gidip eğitim-öğretimle ilgili genel sorunları konuşmalarının öğretmenlerin mesleki gelişimleri için yararlı olacağını belirtmişlerdir. Tablo 6 incelendiğinde öğretmen ve akademisyenlerin önemli bir kısmı güncel bilgiler hakkında öğretmenleri bilgilendirmek için akademisyenlerin okullara gitmelerinin yararlı olacağını söyledikleri dikkat çekmektedir. Konuyla ilgili ÖF2 kodlu öğretmenin düşünceleri,

"Üniversitenin hani diğer ülkelerin makalelerini falan daha iyi takip ettiğinden dolayı, anlarla paralel gitmek açısından, onlara göre bizim öğretimdeki eksikliklerimiz neyse yani güncel bilgiler anlamında destek olurlarsa daha iyi olurlar... özellikle fen çok hızlı gelişiyor, her gün farkh bir bilgi öğreniyoruz ve biz bunun boyutunu bilmiyoruz ne yazık ki." şeklindedir.

Bunun yanında ÖT2, ÖF2 kodlu öğretmenler ve AT1, AF1 kodlu akademisyenler, akademisyenlerin okullarda gözlem yaparak sorunları yerinde tespit etmeleri gerektiğini belirtmişlerdir. Bazı öğretmen ve akademisyenler ise akademisyenlerin okullarda gözlem yapmalarının hizmet öncesi öğretmen eğitimini yapılandırmaları açısından da yararlı olacağını belirtmişlerdir. Tablo 6 incelendiğinde öğretmenlerin özellikle özel eğitim konularında akademisyenlerin okullara gelerek 
kendilere destek olmasını istedikleri görülmektedir. Bu konuda ÖT2 kodlu Türkçe öğretmeni düşüncelerini,

"Diyelim ki benim sinıfinda okuma yazma bilmeyen bir çocuk var ben ne yapmam gerektiğini bilmiyorum, rehberlik araştırma merkezine giden var, yabanci uyruklu ögrenci var, ben ne yapacă̆ımı bilmiyorum ya da farklı yetenekte öğrenciler var. Nasıl ölçme yapıcam? Özel sinav yapmam gerekiyor, alan uzmanı gelse, buna bu şekilde soru sorulur, şeklinde beni yönlendirse hem çocuğu kaybetmemiş olurum hem de ben öğrenmiş olurum" cümleleriyle dile getirmiştir. ÖF1 kodlu öğretmen ise fikirlerini,

"Benim uğraşacă̆ım şey; fen eğitimi mi, okuma yazması mı? Çocukta kaygı da oluşuyor. Ben tahtadayım, bu dersi ne kadar yapılandırmacı yaparsam yapayım, ne kadar verimli geçirirsem geçireyim çocuk bir noktada tıkanıyor. Tamam deney varsa anlıyor ama iş yazılıya, sınava geldiğinde temel okuma yazman becerileri olmadığ için... yani bunu şeye benzetiyorum; kolonu alt katı atmadan biz gökdelen inşa etmeye çalışıyoruz." cümleleriyle anlatmıştır.

Akademisyenlerin okullara ne tür nedenlerle gitmeleri gerektiğine dair ihtiyaçların araştırıldı ğı araştırma sorusundan elde edilen veriler Tablo 7'deki gibidir.

Tablo 7

Akademisyenlerin Okullara Gitme Gerekçeleri ile İlgili Öğretmen ve Akademisyen Görüşleri

\begin{tabular}{cllc}
\hline \multicolumn{1}{c}{ Tema } & \multicolumn{1}{c}{ Kod } & \multicolumn{1}{c}{ Öğretmen } & Akademisyen \\
\hline \multirow{4}{*}{$\begin{array}{c}\text { Öğrenme } \\
\text { Ortamlarinin } \\
\text { Düzenlenmesi }\end{array}$} & Program değişimi & ÖF1,ÖF2,ÖM2,ÖS2,ÖT1,ÖT2 & AT2,AF2 \\
\cline { 2 - 4 } & Planlama & ÖF1,ÖM1,ÖT1 & - \\
\cline { 2 - 4 } & değerlendirme & ÖF1,ÖT1 & - \\
\cline { 2 - 4 } & Lateryal geliştirme & ÖM1 & - \\
\hline \multirow{2}{*}{$\begin{array}{l}\text { Örnek } \\
\text { Uygulamalar }\end{array}$} & Örnek ders sunumu & ÖT2,ÖS1 & - \\
\cline { 2 - 4 } & Uygulama sinif1 & & AT1,AM1,AS1,AM2,AT2,AF2 \\
\hline
\end{tabular}

Tablo 7 incelendiğinde katılımcı öğretmenlerin tamamına yakınının program değişikliklerinde alanlarındaki akademisyenlerin okullara gelerek kendilerine destek olmalarını istedikleri ortaya çıkmıştır. Verilerin analizinden ortaya çıkan kodlar incelendiğinde öğretmenlerin planlama ve ölçme-değerlendirme konusunda akademisyenlerin okula gelerek kendilerine destek olunmasını istediği görülmektedir. Bu konuda ÖT1 kodlu öğretmen düşüncelerini,

"İletişim yok, olmasın isterdim. Eksiklerimi sormak isterdim ölçmede, planlamada. Örneğin bizi gözlemleyip eksiklerimizi kapatabilirler ve bize örnek olacak uygulamalar yapabilirler" cümleleriyle dile getirmiştir.

Bunun yanında öğrenme ortamlarının düzenlenmesi ile ilgili ortaya çıkan kodlardan biri materyal geliştirme diğeri ise laboratuvardır. Tablo 7 'de bazı öğretmenlerin, akademisyenlerin okula gelerek kendilerine örnek sunumlar yapmalarını istedikleri görülmektedir. Bu konuda ÖT2 kodlu öğretmen ise düşüncelerini,

"Örneğin, bir akademisyen gelsin 8. Sınıflara bir kazanımı anlatsın bakalım. Bir de onu görelim. Aynı yöne bakıyoruz ama paralel çalışmıyoruz. Bir kazanımı bir şarkı ile anlatırım ama sayısal zekası olana nasıl anlatacağım?" cümleleriyle belirtmiştir. Öğretmenlerin örnek ders sunumu isteğine benzer şekilde akademisyenlerin de okullarda kendilerine 
ait derslerinin olmasını istedikleri görülmektedir. Bu konuda, AM1 kodlu akademisyenin

“...Hafta da iki saat, orada diğer branşöğretmeniyle aynı şeyi yapmayacaksın. Sen olayı zenginleştirme, farklılaştırma amaçlı gideceksin. Dolayısıyla bence olumlu olurdu..." şeklinde düşündüğü görülmektedir.

\section{Araştırmanın Üçüncü Alt Araştırma Sorusundan Elde Edilen Bulgular}

"Öğretmenlerin, okullarını ziyaret edecek akademisyen prototipi ile ilgili beklentileri nelerdir?" şeklindeki birinci alt araştırma sorusu ile ilgili bulgular Tablo 8'daki gibidir.

Tablo 8

Öğretmenlerin Okulları Ziyaret Edeceği Akademisyen Prototipi ile İlgili Düşünceleri

\begin{tabular}{llllllll}
\hline & $\begin{array}{l}\text { Yönlendirici } \\
\text { olabilen }\end{array}$ & $\begin{array}{l}\text { Öz- } \\
\text { güven } \\
\text { veren }\end{array}$ & $\begin{array}{l}\text { Danışman } \\
\text { gibi soru } \\
\text { sorulabilen }\end{array}$ & $\begin{array}{l}\text { Eşit } \\
\text { düzeyde } \\
\text { olma }\end{array}$ & $\begin{array}{l}\text { Egosu } \\
\text { olmama }\end{array}$ & $\begin{array}{l}\text { Çekincesiz } \\
\text { iletişim }\end{array}$ & $\begin{array}{l}\text { Arkadaş } \\
\text { gibi } \\
\text { yaklaşıma }\end{array}$ \\
\hline Öğretmen & ÖF1,ÖT1,ÖT2 & ÖM1 & ÖS1,ÖT1 & ÖF2 & ÖT2 & ÖF1 & ÖM1,ÖM2 \\
\hline
\end{tabular}

İlgili tablo incelendiğinde okullara gidecek akademisyenlerin özelliklerinde öncelikle öğretmenlerin yolunu aydınlatıcı yönlendirici, özgüven veren, danışman gibi soru sorulabilen kodlarının ön plana çıktığı belirlenmiştir. ÖT1 kodlu öğretmen bu konuda fikirlerini,

"Bizim eksiklerimizi belirlemek için değil de tamamlamak için gelseler iyi olur, beni mutlu eder ama eleştirmek için olursa problemler çıkar" şeklinde ifade ettiği görülmektedir. Bunun yanında öğretmenlerin eşit düzeyde olabilecekleri akademisyenleri istedikleri de Tablo 8'den görülmektedir. ÖF2 kodlu öğretmen bu konudaki düşüncelerini,

"Üslubu aynı işi yapan iki elemanın fikir alışverişi şeklinde olması lazım. Bizim eksiklerimizi onlar, onlarınkini de biz tamamlamalıyı. Yani eksiklik derken bilgi alışverişi, paylaşım şeklinde." şeklinde dile getirmiştir. Ayrıca öğretmenlerin okullarda karşısındakini küçük görmeyen, egosu olmayan akademisyen istedikleri belirlenmiştir. ÖT2 kodlu öğretmen düşüncelerini,

"Akademisyenler farklı bir egoya bürünüyorlar aynı tarafa bakıyoruz ama sorunlar paylaşılmıyor, akademisyenlerin başların okullara çevirip staja gönderdikleri okullara gelip bu çocuklar nasıl bir süreç izliyor görmeleri lazım." şeklinde ifade etmektedir. Bunun yanında öğretmenlerin arkadaş gibi çekinmeden iletişim kurabilecekleri akademisyenler istedikleri belirlenmiştir. Bu konuda ÖM1 kodlu öğretmen fikirlerini,

"Arkadaş gibi olmalı kızıp yargılayan değil de -sunu yapamıyorsun öğrenememişsin gibi. Rahatlatıcı özgüven veren birisi olmal, diğer türlü olmasa daha iyi." cümleleriyle anlatmaktadir.

\section{Tartışma, Sonuç ve Öneriler}

Mevcut araştırma, akademisyen ve öğretmenler arasındaki iletişimin hizmet sürecindeki öğretmen eğitimine yansımalarının incelenmesi amacıyla yapılmıştır. Bu başlık altında ise araştırmadan elde edilen bulgular, mevcut literatür de göz önüne alınarak tartışılmış, elde edilen sonuca uygun olarak da öneriler geliştirilmiştir.

Çalışmanın birinci alt araştırma sorusuna yönelik olan bulgular incelendiğinde (Tablo 3), öğretmen ve akademisyenler arasında yeterli iletişimin olmadı̆̆ bununla birlikte iletişimin geliştirilmesi gerektiği görülmektedir. Hizmet sürecindeki tüm 
öğretmenleri eğitim fakültelerindeki akademisyenlerin yetiştirdiği düşünülürse hem hizmet sürecindeki öğretmen eğitiminin desteklenmesi hem de eğitimle ilgili diğer sorunların çözülmesinde bu iki grubun iletişim kurması büyük önem arz etmektedir. Bununla birlikte literatürde yapılan çalışmalarla da mevcut çalışmanın bulgularını destekler mahiyettedir (Alkan, Şimşek ve Erdem, 2012; Hacıömeroğlu ve Şahin, 2011; Ogan-Bekiroğlu, Kahveci, İrez, Şeker ve Çakır, 2010; Seçer, Çeliköz ve Kayılı, 2010; Ünver, 2003; Yayla, 2015).

Akademisyen ve öğretmenler arasındaki iletişimi güçlendirmek için katılımcılara, akademisyenlerin okullara gitmesi konusunda ne düşündükleri sorulmuştur. Elde edilen bulgulara göre katılımcıların tamamına yakını akademisyenlerin kesinlikle okullara gidip hizmet sürecindeki öğretmenlere destek olması gerektiğini belirtmişlerdir (Tablo 4). Bunun yanında akademisyenlerin okullara ne kadar sıklıkla gitmesi gerektiği konusunda ise örneklemde büyük oranda haftada 2-3 saat gitmeleri fikrinin ön plana çıktığı bulgulardan görülmektedir. Bunun yanında iki kıdemsiz öğretmen ve bir akademisyen genel bir süre belirtmekle birlikte bu sürenin öğretmen ve akademisyenlerce karşılıklı olarak belirlenmesinin daha yararlı olacağını belirtmişlerdir. Bulgulardaki verilen örnek yanıtlardan da görüldü ŭü gibi öğretmenlerin akademisyenlerin okula gelmesini istedikleri fakat sürenin çok fazla uzun tutulmaması gerektiği ortaya çıkmaktadır. Fakat verilen iki örnek yanıttan da görüldüğü gibi bunun nedenleri farklılık göstermektedir. Burada bir öğretmen akademisyenlerin ortamda fazla bulunmasının kendisi için güven oluşturacağ fakat akademisyene güvenerek kendisinin yeterince gelişemeyeceğini belirtirken diğer öğretmen, sınıfında birinin çok fazla bulunmasından duyacağı rahatsızlığı dile getirmektedir. Bunun temel nedenin ise öğretmenlerin performans kaygılarından kaynaklanabileceği gibi ortamda farklı birinin bulunmasının doğal öğrenme ortamına zarar verebileceği düşüncesinden de kaynaklanabileceği düşünülmektedir. Literatürde de yapılan araştırmalara bakıldığında öğretmenlerin veya öğretmen adaylarının, akademisyenleri okullarda daha fazla görmek istedikleri ve daha çok bir araya gelmeleri gerektiklerini ifade ettikleri görülmektedir (Bilgin-Aksu, 2004; Seçer, Çeliköz ve Kayılı, 2010; Yayla, 2015; Sıcak ve Parmaksız, 2016; Kirman-Bilgin, KalaAydin ve Sungur-Alhan, 2017).

Araştırmanın ikinci alt araştırma sorusu kapsamında elde edilen bulgular incelendiğinde örneklemdeki her iki grubun da akademisyenlerin okullara gitmesi gerektiği konusunda hem fikir olmalarına rağmen akademisyenlerin okullara gidip öğretmenlerle görüşmelerinde çeşitli sorunlarla karşılaşabileceklerini belirttikleri görülmektedir (Tablo 5). Okulu ziyaret etme sürecinde akademisyenlerin en fazla vurguladıkları sorunlar ise MEB'in prosedürleri, müdürlerin engel çıkarabileceği ve ikili ilişkiler olmazsa rahat görüşemeyecekleridir. Akademisyenlerin ortaya koydukları bu sorunların ise daha önceki deneyimlerine dayandığı düşünülmektedir. Bu noktada literatüre bakıldı̆̆ında, eğitim fakülteleri, $\mathrm{MEB}^{\prime}$ den izin alma sürecinin hızlandırılması ve belirli bir standart getirilmesi konusunda destek talep ettiklerini ifade eden araştırmalar mevcuttur (Bozan vd., 2004). Akademisyenler bu kadar sorundan bahsederken öğretmenlerin akademisyenlerin yoğunluğu dişında sorun görmemeleri dikkat çekici bir durumdur. Bunun nedeninin ise akademisyenlerin okula gittiklerinde yaşadıkları sorunlar hakkında öğretmenlerin fikrinin olmamasından kaynaklanabileceği düşünülmektedir. Literatüre bakıldığında 
akademisyenlerin fakültelerdeki ders yüklerinin fazlalığı (Yeşil ve Çalışkan, 2006), araştırma yapma ve araştırma raporu yazma gibi iş yüklerinin olması nedeniyle öğrenme ortamlarını gözlemleyemediklerini ifade eden araştırmalara rastlanmaktadır (Sakl1, 2017).

Öğretmenlerin gerek performans kaygılarının giderilmesinde gerekse akademisyenleri sınıflarının bir üyesi gibi kabul etmelerinde akademisyenlerin kişilik özellikleri büyük önem taşımaktadır. Bulgular incelendiğinde (Tablo 8), öğretmenlerin kıdemine göre akademisyenlerin kişilik özelliklerine dair beklentilerinin değişiklik arz ettiği söylenebilir. Kıdemsiz öğretmenler daha fazla "yolumu aydınlatıcı yönlendirici” ve "danışman gibi soru sorulabilen" kodlarında yoğunlaşmışlardır. Bu kodlarda yoğunluğun yaşanmasının temel nedeninin bu öğretmenler yeni mezun olduğu için akademisyenleri hala soru sorulabilecek, danışılabilecek bilgili kişiler olarak görmelerinden kaynaklanabileceği düşünülmektedir. Kıdemli öğretmenlerde ise "eşit düzeyde olmalıyı", "arkadaş gibi" ve "akademisyen egosu olmamalı" kodları ön plana çıkmaktadır. Dolayısıyla buradan, kıdemli öğretmelerin kendilerine doğrudan danışman gibi yaklaşacak akademisyenlerden ziyade karşılıklı paylaşımlarda bulunabileceği kişilik özelliğini tercih ettikleri görülmektedir. Bunun nedenin ise kıdemli öğretmenlerin kendilerinde çok büyük bir eksiklik görmemelerinden kaynaklanabileceği düşünülmektedir. Azar (2003) yaptığı araştırmasında, hizmet öncesi eğitim sürecinde Okul Deneyimi ve Öğretmenlik Uygulaması derslerini yürüten uygulama öğretmenlerinin, akademisyenler tarafından yeterince aydınlatılmadıkları ve bilgilendirilmedikleri sonucunu elde etmiştir.

Katılımcıların, akademisyenlerin okullara gitmelerinin yararlı olacağı konusunda hemfikir olmakla birlikte akademisyenlerin okullarda yapması gereken bazı faaliyetler konusunda farklı görüşlerde oldukları bulgulardan görülmektedir. Bu anlamda öğretmenlerin en fazla "öğrenme ortamlarının düzenlenmesi" temasında yoğunlaştığı dikkat çekmektedir ki burada da daha fazla "program değişimi" görüşünde oldukları (Tablo 7) görülmektedir. Bu kodun bu kadar ön plana çıkmasının nedeni olarak, program değişimiyle birlikte öğretmenlerin öğretim tasarımları da büyük oranda değiştiği için bu konuda akademisyenlerden destek istedikleri düşünülmektedir. Öğretmenlerin, "planlama", "ölçme değerlendirme", "materyal geliştirme" ve "laboratuvar" kodlarını da vurgulaması (Tablo 7) onların öğretim tasarımı konusundaki ihtiyaçlarını bir kez daha gündeme getirmektedir. İlgili literatürde de öğretmenlerin benzer ihtiyaçlardan dolayı akademisyen desteğine ihtiyaç duydukları ortaya konulmuştur (Kirman-Bilgin, Kala-Aydın ve Sungur-Alhan, 2017; Sıak ve Parmaksız, 2016). Öğretmenlerin akademisyenlerin sahada olmasını istedikleri bir diğer alan ise davranış bozukluğu veya özel eğitime ihtiyaç duyan öğrencilerin eğitimi konusunda olduğu görülmektedir. Sıcak ve Parmaksız (2016) da yaptıkları araştırmada benzer bulgulara rastlamıştır.

Mevcut araştırmada ikinci alt araştırma sorusu kapsamında akademisyenlerin okullara gitme gerekçeleri ile ilgili her iki grupta ön plana çıkan kodların, "kazanılması zor konular", "güncel bilgiler", "sorunların yerinde tespiti" ve "hizmet öncesi öğretmen eğitimi" olduğu (Tablo 6) belirlenmiştir. Buradan her iki grubun da akademisyenlerin okullara gelerek eğitim-öğretimle ilgili genel sorunları öğretmenlerle görüşmesinin, hem eğitimdeki sorunların hem de öğretmen mesleki gelişimleri açısından yararlı olacağı görüşünde büyük oranda hemfikir oldukları 
görülmektedir. Bu bulgunun literatürdeki bulgularla büyük benzerlik gösterdiği de belirlenmiştir (Bilgin-Aksu, 2004; Seçer, Çeliköz ve Kayılı, 2010; Tonbul ve Altınay, 2010; Ünver, 2003; Yayla, 2015). Bulgulardan akademisyenlerin okullara giderek güncel bilgiler konusunda öğretmenleri bilgilendirmesinin yararlı olacağ1 görüşünün her iki grupta da ön plana çıktığı görülmektedir. Verilen örnek yanıttan da görüldüğü gibi bunun temel nedeninin, öğretmenlerin akademik çalışmaları yeterince takip etmemelerinin ve bu konuda yeterince bilgilendirilmediklerinin olduğu düşünülmektedir. Bozan, vd. (2004), üniversitelerde tamamlanan eğitim araştırmalarının geniş bir özetinin il millî eğitim müdürlüklerine gönderilmesinin sağlanılması ve araştırma sonuçlarının gereken hâllerde bir sunu ile tanıtılması ile ilgili paylaşım faaliyetlerini düzenleyecek ilgili birimlerin kurulmasına yönelik tespitlerde bulunmuşlardır. Benzer şekilde Çepni ve Küçük (2003), öğretmenler ve akademisyenler arasında etkili bir iş birliğinin sağlanması ve eğitim alanında yapılan araştırmaların sonuçlarının öğretmenlere duyurulması gerektiğini tespit etmişlerdir. Bunun yanı sıra özellikle fen bilimleri öğretmenlerinin güncel bilgiler konusunda destek istemelerinin temel nedeninin ise eğitim alanındaki güncel bilgilerden ziyade alanla ilgili güncel bilgiler olduğu öğretmenlerden birinin verdiği yanıttan da görülmektedir. Literatürde yapılan çalışmaların sonuçlarına bakıldı̆̆ında teknolojinin ve bilginin hızla gelişim ve değişim göstermesi sebebi ile fen bilimleri öğretmenlerinin bilimsel eksiklerinin giderilmesi gerektiği üzerinde önemle durmuşlardır (Ayvacı, Bakırcı ve Yıldız, 2014; Gültekin ve Çubukçu, 2008; Sarıgöz, 2011; Şenel, 2008). Bu düşünceye ek olarak akademisyenlerin okullara giderek sorunları yerinde tespit etmelerinin, hem bu sorunlarla ilgili akademik çalışmalar yaparak daha gerçekçi çözümler üretmelerinde hem de bu doğrultuda da hizmet öncesi öğretmen eğitimini yapılandırmaları konusunda yararlı olacağı fikri her iki grupta da ön plana çıktığı bulgulardan görülmekte olup, bu bulgu Yayla (2015)'nın yaptığ1 araştırmanın sonuçları ile örtüşmektedir. Öğretmenlerle akademisyenler arasında kısmen de olsa görüş ayrılığının yaşandı̆̆ı durumlardan birinin de "örnek uygulamalar" temasında (Tablo 7) olduğu bulgulardan görülmektedir. Burada öğretmenler, akademisyenlerin okullara gelerek kendileri için örnek sunumlar yapmalarını istemektedirler. Örnek ders sunumu koduyla ilgili kıdemsiz bir öğretmenin cümlesinden bu dersi gerçekten örnek almak için istediği görülürken kıdemli öğretmenin cümlesinde daha ziyade meydan okuma ifadesinin olduğu görülmektedir. $\mathrm{Bu}$ durum ise kıdemsiz öğretmenlerin akademisyenleri danışman olarak okullarda görmek isterken kıdemli öğretmenlerin kendilerini mesleki gelişimde daha yeterli gördükleri için akademisyenlerle ego yarışına girdikleri düşüncesini doğurmaktadır. Literatürde yapılan araştırmalara bakıldığında kıdemli öğretmenlerin mesleki açıdan kendilerini daha yeterli gördükleri, her zaman gelişim ve öğrenmeye açık olmadıkları (İlğan, 2013) ve bunun sebebi olarak da öğretmenlerin edindikleri deneyimlerin etkisinin olduğu tespit edilmiştir (Yeşilyurt ve Çankaya, 2008). Bulgulardan akademisyenlerin ise tüm yıl boyunca bir sınıfın kendilerine ait olmasını istedikleri (Tablo 7) görülmektedir. Akademisyenlerden birinin cümlesinden de görüldügü gibi bunun nedenlerinden biri, okuldaki diğer öğretmenler için akademisyenlerin öğretim tasarımlarının farklılık yaratacağı düşüncesidir. Bir diğer nedeni ise, akademisyenlerin okullarda saha deneyimi kazanarak hem akademik çalışmalarını hem de hizmet öncesi öğretmen eğitimini yapılandırma çabalarının yattığı düşünülmektedir. Ogan-Bekiroğlu, vd. 
(2010), öğretmen adayları tarafından sürekli ders işleyebilecekleri bir pilot sınıfın olması ve öğretim üyeleri tarafından gözlemlenmeleri gerektiği sonucunu elde ederken, Yayla (2015) ise üniversitelerin kendi uygulama okullarının açılması gerektiğini ve bu sayede hem öğretmen adaylarının hem de akademisyenlerin daha fazla uygulama ortamlarında bulunmalarının să̆lanması gerektiğini belirtmiştir.

Özetle araştırmada, katılımcı akademisyen ve öğretmenlere göre öğretmen ve akademisyenler arasında yeterli iletişimin olmadığı sonucuna varılmıştır. Öğretmenler ve akademisyenlerin, aralarındaki iletişimi geliştirmek için akademisyenlerin okullara giderek öğretmenlere rehberlik yapmalarının yararlı olacağ1 düşündükleri tespit edilmiştir. Akademisyenlerin okullara ne kadar sıklıkla gitmesi gerektiği konusunda ise örneklemde büyük oranda haftada 2-3 saat gitmeleri görüşünün ön plana çıtı̆̆ı belirlenmiştir. Bununla birlikte akademisyenlerin okullara rahatça gidebilmeleri için öğretmenlerle etkili iletişim süreçleri içerisinde olmaları gerektiği tespit edilmiştir. Bu süreçte akademisyenlerin, MEB'deki bazı prosedürleri ve müdürleri en temel sorun olarak gördükleri ortaya çıkmıştır. Ayrıca mevcut araştırmada, okullara giderek öğretmenlere rehberlik yapacak akademisyenlerin kişilik özelliklerinin kıdeme göre değişkenlik arz ettiği ortaya çıkmıştır. Bu bağlamda, kıdemli öğretmenlerin kendilerine arkadaş gibi hissedebilecekleri akademisyen profilini; kıdemsiz öğretmenlerin ise kendilerini süreçte yönlendirecek, danışmanlık yapacak akademisyen profilini tercih ettikleri sonucuna varılmıştır.

Akademisyenlerin okullara gitmesinin kurumlar arasındaki iletişimi artıracağ konusunda hem akademisyenlerin hem de öğretmenlerin hemfikir olmasına rağmen akademisyenlerin okulda bulunma gerekçelerinde bazı farklılıklar olduğu belirlenmiştir. Akademisyenlerin hem öğretmenlerin mesleki gelişimleri hem de kendilerinin akademik çalışmaları için kendilerine ait bir uygulama sınıfı istedikleri görülmektedir. Araştırma sonucunda, akademisyenlerin okullara giderek eğitimöğretimle ilgili genel sorunları konuşmalarının ve araştırmalarla ilgili güncel bilgiler vermelerinin öğretmenlerin mesleki gelişimleri için yararlı olacağı konusunda akademisyen ve öğretmenlerin büyük çoğunluğunun paralel düşündüğü ortaya çıkmıştır. Öğretmenlerin tamamına yakınının alanlarındaki program değişimi ile ilgili bilgilendirmek ve örnek ders sunumu yapmak için akademisyenlerin okullara gelmesi gerektiği belirlenmiştir. Bunun yanında örneklemdeki akademisyenlerden ziyade öğretmenlerin planlama, ölçme-değerlendirme, materyal geliştirme, laboratuvar ve hizmet öncesi öğretmen eğitimi konusunda akademisyenlerin okula gelerek kendilerine destek olunmasını istediği sonucuna varılmıştır. Öğretmenlerin, özellikle özel eğitime ihtiyaç duyan öğrencilerin ve davranış bozukluğu olan öğrencilerin eğitim-öğretimi sürecinde akademisyenlerin desteğine ihtiyaç duydukları belirlenmiştir.

Araştırmadan elde edilen bu sonuçlara dayanarak aşağıdaki öneriler geliştirilmiştir;

- $\quad$ Akademisyen öğretmen iletişimini geliştirmek için YÖK ve MEB arasında, akademisyenlerin uygulama yapmadan sadece katılımcı gözlemci olarak sınıflara girebilmesine, öğretmenler odasında öğretmenlerle eğitim öğretime dair görüşmeler yapabilmesine olanak tanıyan protokoller imzalanmasının yararlı olabileceği düşünülmektedir. 
- $\quad$ Eğitim fakülteleriyle il milli eğitim müdürlükleri arasında akademisyen öğretmen ilişkisini artırmaya yönelik sosyal aktivitelerin düzenlenmesi önerilmektedir.

- $\quad$ YÖK ve MEB arasında imzalanacak bir protokolle, akademisyenlerin hizmet sürecindeki öğretmen eğitimindeki bazı uygulama derslerine öğretmenleri davet etmelerinin öğretmenlerin güncel uygulamaları görmeleri açısından yararlı olacağı düşünülmektedir. Bu uygulamanın aynı zamanda öğretmen, öğretmen adayı ve akademisyenler arasındaki iletişimin gelişimine de katkı sağlayacağı düşünülmektedir.

\section{Kaynakça}

Abazoğlu, İ. (2014). Dünyada öğretmen yetiştirme programları ve öğretmenlere yönelik mesleki gelişim uygulamaları. Turkish Studies, 9(5), 1-46.

https:// eds.b.ebscohost.com/eds/pdfviewer/pdfviewer?vid=0\&sid=6fc1cae 0-30f6-4a4b-921a-ea6e1a4e7d93\%40pdc-v-sessmgr03 15.04.2021 tarihinde erişilmiştir.

Alkan, V., Şimşek, S. ve Erdem, A. R. (2013). Uygulama okullarındaki yönetici ve eğitici personelin okul deneyimi dersine ilişkin önerileri. Education Sciences, 8(2), 245-260. http:/ /dx.doi.org/10.12739/NWSA.2013.8.2.1C0585

Ayvacı, H. Ş., Bakırcı, H., ve Yıldız, M. (2014). Fen bilimleri öğretmenlerinin hizmet içi eğitim uygulamalarına ilişkin görüşleri ve beklentileri. Amasya Üniversitesi Eğitim Fakültesi Dergisi, 3(2), 357-383. https:// dergipark.org.tr/en/download/article-file/19629 15.04.2021 tarihinde erişilmiştir.

Azar, A. (2003). Okul deneyimi ve öğretmenlik uygulaması derslerine ilişkin görüşlerinin yansımaları. Milli Eğitim Dergisi, Ankara, sayı-159. http://dhgm.meb.gov.tr/yayimlar/dergiler/milli_egitim_dergisi/159/azar. $\mathrm{htm}$ adresinden 11.05.2018 tarihinde erişilmiştir.

Bilgin-Aksu, M. (2004). Fakülte-okul işbirliği semineri ve uygulama sürecinin değerlendirilmesi: Malatya ili örneği. XIII. Ulusal Ĕ̆itim Bilimleri Kurultayı, İnönü Üniversitesi, Malatya.

http://www.pegem.net/dosyalar/dokuman/399.pdf 15.04.2021 tarihinde erişilmiştir.

Bozan, M., Yayla, D., Demirbaş, A., Sayın, M., Saygın, Ö. ve Yağız, Z. (2004). Eğitim araştırmalarında meb-üniversite iş birliği. http://haydikizlarokula.meb.gov.tr/earged/earged/Meb_Universite_isbirli gi.pdf 03.07.2018 tarihinde erişilmiştir.

Çepni, S. ve Küçük, M. (2003). Eğitim araştırmalarının fen bilgisi öğretmenlerinin uygulamaları üzerindeki etkilerinin belirlenmesi: bir örnek olay çalışması. Ĕ̈itim Araştırmaları Dergisi, 4(12), 75-84. https://www.researchgate.net/publication/292756693 16.04.2021 tarihinde erişilmiş̧ir.

Dallmer, D. (2004). Collaborative relationships in teacher education: A personal narrative of conflicting roles. Curriculum Inquiry, 34(1), 29-45. https:// doi.org/10.1111/j.1467-873X.2004.00279.x 
Ekinci, Ö. ve Yıldırım, A. (2009). İl eğitim denetmenleri ve ilköğretim okulu yöneticilerinin hizmet içi eğitim faaliyetlerine yönelik beklentileri. Ege Ĕ̆itim Dergisi, 10(1), 70-91. https:/ / dergipark.org.tr/en/download/articlefile/57038 15.04.2021 tarihinde erişilmiştir.

Eraslan, A. (2008). Fakülte-okul işbirliği programı: matematik öğretmeni adaylarının okul uygulama dersi üzerine görüşleri. Hacettepe Üniversitesi Eğitim Fakültesi Dergisi, 34, 95-105. https:/ / dergipark.org.tr/en/download/article-file/87544 15.04.2021 tarihinde erişilmiştir.

Gökçe, E. ve Demirhan, C. (2005). Öğretmen adaylarının ve ilköğretim okullarında görev yapan uygulama öğretmenlerinin öğretmenlik uygulaması etkinliklerine ilişkin görüşleri. Ankara Üniversitesi Ĕ̆itim Bilimleri Fakültesi Dergisi, 38(1), 43-71. https:/ / dergipark.org.tr/tr/download/articlefile/509172

Gökdere, M. ve Çepni, S. (2004). Üstün yetenekli öğrencilerin fen öğretmenlerinin hizmet içi ihtiyaçlarının değerlendirilmesine yönelik bir çalışma: bilim sanat merkezi örneklemi, Gazi Eğitim Fakültesi Dergisi, 2(24), 1-14.

http:/ / www.gefad.gazi.edu.tr/en/download/article-file/77314 16.04.2021 tarihinde erişilmiştir.

Gönen, S. ve Kocakaya, S. (2006). Fizik öğretmenlerinin hizmet içi eğitimler üzerine görüşlerinin değerlendirilmesi, Pamukkale Üniversitesi Eğitim Fakültesi Dergisi, 19(1), 37-44. https:/ / dergipark.org.tr/en/download/article-file/114742 16.04.2021 tarihinde erişilmiştir.

Gültekin, M. ve Çubukçu, Z. (2008). İlköğretim öğretmenlerinin hizmet içi eğitime ilişkin görüşleri. Sosyal Bilimler Dergisi, 19, 185-201. https:/ / dergipark.org.tr/en/ download/article-file/843617 16.04.2021 tarihinde erişilmiştir.

Hacıömeroğlu, G. ve Şahin, Ç. (2011). Sınıf öğretmeni adaylarının uygulama öğretmenleri hakkındaki özel alan yeterlikleri algısı. Mustafa Kemal Üniversitesi Sosyal Bilimler Enstitüsü Dergisi, 8(15), 473-486. https:/ / dergipark.org.tr/en/download/article-file/183328 16.04.2021 tarihinde erişilmiştir.

İlğan, A. (2013). Öğretmenler için etkili mesleki gelişim faaliyetleri. Uşak Üniversitesi Sosyal Bilimler Dergisi, 14, 41-56. https:/ / dergipark.org.tr/en/download/article-file/202279 15.04.2021 tarihinde erişilmiştir.

Johnson, B. and Christensen, L. (2012). Educational Research: Quantitative, Qualitative, and Mixed Approaches (Fourth Ed.), Los Angeles: Sage Publications.

Kala, N., Sungur-Alhan, S. ve Kirman-Bilgin, A. (2019). Akademisyen ve Öğretmen Perspektifinden Türkiye' deki Hizmet Sürecindeki Öğretmen Eğitiminin İncelenmesi) Yüzüncü Yıl Üniversitesi Eğitim Fakültesi Dergisi, 16(1), 1277-1307. http:/ / dx.doi.org/10.23891/efdyyu.2019.161

Karakaya, Y. E. and Brusseau, T. A. (2015). School of university-practice collaboration program in the united states and turkey: views and experiences of candidates of physical education and sport teacher. Paper proposed to be presented at the conference for the International Society for Social Sciences of Sport, Budapest, Hungary. 
Karasu-Avc1, E. ve Ünal-İbret, B. (2016). Öğretmenlik uygulaması-II dersine ilişkin okul öncesi öğretmen adaylarının görüşlerinin değerlendirilmesi. Kastamonu Ĕ̆itim Dergisi, 24(5), 25-19. https:// dergipark.org.tr/en/download/articlefile/309466 16.04.2021 tarihinde erişilmiştir.

Kirman-Bilgin, A., Kala-Aydın, N. ve Sungur-Alhan, S. (2017, April). Fen bilimleri öğretmenlerinin mesleki eğitim ihtiyaçlarnna yönelik görüşlerinin incelenmesi. 26. Uluslararası Eğitim Bilimleri Kongresi (ICES-UEBK 2017). Side, Türkiye.

Mete, Y. A. (2013). Güney Kore, Japonya, Yeni Zelanda ve Finlandiya'da öğretmen yetiştirme ve atama politikalari. Electronic Turkish Studies, 8(12), 859-878. https:// doi.org/10.7827/TurkishStudies.5916

Miles, M, B. and Huberman, A. M. (1994). Qualitative data analysis: an expanded sourcebook. (2nd ed). Thousand Oaks, CA: Sage Publications.

Özkılıç, R., Bilgin, A. ve Kartal, H. (2008). Öğretmenlik uygulaması dersinin öğretmen adaylarının görüşlerine göre değerlendirilmesi. İlköğretim Online, 7(3), 726-737.

Ogan-Bekiroğlu, F., Kahveci, A., İrez, S., Şeker, H. ve Çakır, M. (2010). Fakülte-okul işbirliği modelinin değerlendirilmesi: ortaöğretim fen alanları öğretmen adaylarının görüşleri. Türk Fen Eğitimi Dergisi, 7(4), 148-168. https://www.pegem.net/dosyalar/dokuman/124796-2011090217226-11.pdf 16.04.2021 tarihinde erişilmiştir.

Saklı, A. R. (2017). Recep Tayyip Erdoğan Üniversitesi öğrenci ve akademisyenleri ile Rize halkının karşılıklı algı ve beklentileri. Rize: Recep Tayyip Üniversitesi Yayınları.

Sarıgöz, O. (2011, A pril). İlköğretim öğretmenlerinin hizmet içi eğitim faaliyetleri ile ilgili görüşlerinin değerlendirilmesi. II. International Conference on New Trends in Education and Their Implications, Antalya, 27-29.

Seçer, Z., Çeliköz, N. ve Kayılı, A. G. G. (2010). Okul öncesi öğretmenliği okul uygulamalarında yaşanan sorunlar ve çözüm önerileri. Yüzüncü Yıl Üniversitesi Eğitim Fakültesi Dergisi, 7(1), 128-152.

https:/ / dergipark.org.tr/en/ download/article-file/146284 16.04.2021 tarihinde erişilmiştir.

Sıcak, A. ve Parmaksız, R. Ş. (2016). İlköğretim kurumlarındaki mesleki çalışmaların etkililiğinin değerlendirilmesi. Inönü Üniversitesi Ĕ̆itim Fakültesi Dergisi, 17(1), 17-33. https:// doi.org/10.17679/iuefd.17144668

Silay, İ. ve Gök, T. (2004). Öğretmen adaylarının uygulama okullarında karşılaştıkları sorunlar ve bu sorunları gidermek amacıyla hazırlanan öneriler üzerine bir çalışma. XIII. Ulusal Eğitim Bilimleri Kurultayı, İnönü Üniversitesi, Malatya.

Şenel, T. (2008). Fen ve teknoloji öğretmenleri için alternatif ölçme ve değerlendirme tekniklerine yönelik bir hizmet içi ĕgitim programının etkililiğinin araştırılması. (Yayımlanmamış yüksek lisans tezi). Karadeniz Teknik Üniversitesi Fen Bilimleri Enstitüsü, Trabzon.

Tonbul, Y. ve Altınay, E. (2010). Eğitim fakültelerinin öğretmenlerin mesleki gelişimine katkısı. E-Journal of New World Sciences Academy, 6(3), 2188-2209.

Ünver, G. (2003). Öğretmenlik uygulamasında işbirliği: bir durum çalışması. Gazi Ĕ̆itim Fakültesi Dergisi, 23(1), 87-100. http:/ / www.gefad.gazi.edu.tr/en/download/article-file/77387 16.04.2021 tarihinde erişilmiştir. 
Yalın-Uçar, M. (2012). Öğretmenlik uygulamasına ilişkin durum çalışması. Kuram ve Uygulamada Ĕ̆itim Bilimleri, 12(4), 2637-2660.

Yayla, A. (2015). Nitelikli öğretmenlerin yetiştirilme sürecinde yeni arayışlar: Sorunlar ve çözüm önerileri. TYB Akademi Dil Edebiyat ve Sosyal Bilimler Dergisi, 13, 109-122.

https:/ / www.tybakademi.com/kitap/akademi13.pdf\#page=109 16.04.2021 tarihinde erişilmiştir.

Yeşil, R. ve Çalışkan, N. (2006). Okul Deneyimi 1 dersinde işbirliği sürecinin değerlendirilmesi (Kırşehir Eğitim Fakültesi Örneği). Kuram ve Uygulamada Ĕ̈itim Yönetimi Dergisi, 12(2), 277-310.

Yeşilyurt, E. ve Çankaya, İ. (2008). Sinıf yönetimi açısından öğretmen niteliklerinin belirlenmesi. Elektronik Sosyal Bilimler Dergisi, 7(23), 274-295.

Yıldırım, A. ve Şimşek, H. (2008). Sosyal bilimlerde nitel araştırma yöntemleri. Ankara: Seçkin Yayıncılık.

\section{Summary}

\section{Introduction}

The communication between academicians who prepare the candidate teachers for this profession and the candidates is generally cut off after graduation. In-service training seminars are among the means of establishing this communication in Turkey. If a teacher, who has started serving wants to receive training in a topic that he/she wants to develop himself/herself in and if there are academicians who have taken part in this training then it is a perfect opportunity to establish academician - teacher communication. In addition, academicians and teachers mostly make contact thanks to the school experience of candidate teachers and applied teaching courses. The studies carried out indicate that there are significant issues in these cooperation and communication processes as well as the necessity of establishing physical environments where observers can come together to make evaluations in order to overcome these issues (Yeşil and Çalışkan, 2006). Karakaya and Brusseau (2015) and Yalın-Uçar (2012) reported that sufficient communication between university and schools should be established in order to carry out these processes properly, but that both sides are uninterested.

Candidate teachers are educated by academicians throughout their candidacy periods. Therefore, it is natural that they should want to communicate with academicians in order to keep up with related developments in the field and to meet their demands by way of cooperation. It is an issue of interest as to what the opinions are of teachers and academicians who play an effective role in the pre-service and inservice professional development stages in our country regarding how the communication between teachers and academicians should be established and how this communication should be structured in order to meet the individual needs of teachers. If it is considered that the main reason for the establishment of this communication and cooperation is to increase the academic success of students regardless of discipline, we are of the opinion that the study shall not only make significant contributions to the literature but also to the application as well. 


\section{Methodology}

The objective of this study is to examine the impact of the relationship between academicians in education faculties and the teachers on the training of in-service teachers and to develop solution suggestions for the issues that emerged in these areas. Phenomenology method was used in the study. Four disciplines including Science Education, Mathematics Education, Social Sciences Education and Turkish Education were taken into consideration when determining the participants of the study on account of the fact that teachers and academicians in different disciplines may have different perspectives regarding the communication between academicians and teachers. In addition to the disciplines of the participating teachers, two different seniority groups were determined for the teachers including those with seniority (with an experience of over 10 years) and those without seniority (in the first two years of his/her profession) based on the idea that seniority may be effective for developing different ideas related with the study topic. Accordingly, the participants of the study included eight academicians working in the aforementioned four departments of a state university in Turkey and eight teachers working in the aforementioned disciplines as part of the Provincial Directorate of National Education in the city where this university is located. Data in the study were obtained via semi-structured interviews. Two different semi-structured interview forms have been developed for this purpose including one for the teachers and one for the academicians. Data collected during the interviews were analyzed by means of content analysis.

\section{Results and Discussion}

It can be observed from the obtained data that the communication between the teachers and academicians is insufficient and that it has to be improved. When it is considered that all in-service teachers are educated by the academicians in the faculties of education, establishing a proper communication between these two groups holds significant importance for solving the issues related with providing support to inservice teachers in addition to other education related issues. In addition, the studies carried out in literature support the findings of this study (Alkan, Şimşek and Erdem, 2012; Hacıömeroğlu and Şahin, 2011; Ogan-Bekiroğlu, Kahveci, İrez, Şeker and Çakır, 2010; Seçer, Çeliköz and Kayıl1, 2010; Ünver, 2003; Yayla, 2015). The participants were asked what they think about the academicians visiting schools for improving the communication between the academicians and teachers. According to the acquired results, almost all the participants have indicated that academicians should definitely visit the schools and support in-service teachers.

It can be seen from the results that the participants have different opinions on activities that the academicians should carry out at schools. In this regard, it was observed that teacher opinions focused mostly on the "arrangement of learning environments" theme and the "program change" code that is a part of this theme. It is thought that the reason why this code has come to the forefront is that teachers want the support of academicians due to the significant change in the instructional designs. As it can be seen from the findings, teachers' emphasis on the codes of "planning", "measurement and evaluation", "material development" and "laboratory" once more brings up the need of the teachers for instructional design. The relevant literature has also reported that teachers require academician support due to similar needs (Sicak and Parmaksız, 2016; Kirman-Bilgin, Kala-Aydın and Sungur-Alhan, 2017). Another 
area that the teachers want the academicians to take on in the field is the education of students with behavioral disorder or those who need special education. Sicak and Parmaksiz (2016) concluded similar findings in their study. It was revealed that the codes of "general issues in education", "current knowledge", "on-site determination of issues" have come to the forefront in both groups.

\section{Pedagogical Implications}

Based on these results obtained from the research, the following suggestions have been developed;

- In order to improve the communication between academics and teachers, it is thought that it would be beneficial to sign protocols between Council of Higher Education (CHE) and Ministry of National Education (MNE) that allow academics to enter the classes only as participant observers without any practice, and to conduct education-related discussions with teachers in the teachers' room.

- With a protocol to be signed between CHE and MNE, it is thought that it would be beneficial for the academicians to invite teachers to some practical lessons in teacher education in the service process in order to see the current practices of the teachers. This practice is also thought to contribute to the development of communication between teachers, candidate teachers and academics.

\section{Araştırmanın Etik İzinleri}

Yapılan bu çalışmada "Yükseköğretim Kurumları Bilimsel Araştırma ve Yayın Etiği Yönergesi" kapsamında uyulması belirtilen tüm kurallara uyulmuştur. Yönergenin ikinci bölümü olan "Bilimsel Araştırma ve Yayın Etiğine Aykırı Eylemler" başlı̆̆ı altında belirtilen eylemlerden hiçbiri gerçekleştirilmemiştir.

Etik kurul izin bilgileri

Etik değerlendirmeyi yapan kurul ad1 $=$ Sosyal ve Beşeri Bilimler Etik Kurulu

Etik değerlendirme kararının tarihi= 30.12.2016

Etik değerlendirme belgesi sayı numarası $=04$

\section{Yazar Bilgileri/Authors' Biodata}

Nesli KALA, lisans eğitimini Karadeniz Teknik Üniversitesi Eğitim Fakültesi Kimya Öğretmenliği bölümünde tamamlamıştır. Yüksek lisansını Kafkas Üniversitesi İlköğretim Bölümü Fen Bilgisi Eğitiminde, doktorasını Karadeniz Teknik Üniversitesi Eğitim Bilimleri Enstitüsü Kimya Eğitimi alanında yapmıştır. Yazar, halen Kafkas Üniversitesi'nde Dr. Öğr. Üyesi olarak görev yapmaktadır.

Nesli Kala, completed her undergraduate education at Karadeniz Technical University, Fatih Faculty of Education, Department of Chemistry Teaching. She, completed her master's degree in Science Education at Kafkas University, Department of Primary Education, and her PhD in Chemistry Education at Karadeniz Technical University, Institute of Educational Sciences. The author continues to work as assistant profesor in Kafkas University.

Arzu KİRMAN BİLGİN, Kafkas Üniversitesi Fen Bilgisi Öğretmenliği Programindan mezun olmuştur. Yüksek lisansını Kafkas Üniversitesi Fen Bilimleri Enstitüsü Fen Bilgisi Eğitiminde, doktorasını ise Karadeniz Teknik Üniversitesi Eğitim Bilimleri 
Enstitüsü Fen Bilgisi Eğitimi Programında yapmıştır. Yazar, halen Kafkas Üniversitesi'nde Dr. Öğr. Üyesi olarak görev yapmaktadır.

Arzu Kirman Bilgin graduated from the Kafkas University Science Teaching Program. She completed his master's degree in Science Education Graduate School of Natural and Applied Sciences at Kafkas University and her PhD in Science Education Department of Karadeniz Technical University, Institute of Educational Sciences. The author continues to work as assistant profesor in Kafkas University.

Selcan SUNGUR ALHAN, lisansını Fırat Üniversitesi Fen Bilgisi Öğretmenliği Programında tamamlamıştır. Yazar yüksek lisansını Fırat Üniversitesi Eğitim Bilimleri Enstitüsü Fen Bilgisi Eğitiminde, doktorasını ise Atatürk Üniversitesi Eğitim Bilimleri Enstitüsü Fen Bilgisi Eğitiminde yapmıştır. Kafkas Üniversitesi Dede Korkut Eğitim Fakültesi'nde Dr. Öğretim Üyesi olarak görev yapmaktadır.

Selcan Sungur Alhan graduated from Firat University Science Teaching Program. The author completed her master's degree in Science Education at Frrat University, Institute of Educational Sciences, and her $\mathrm{PhD}$ in Science Education at Atatürk University Institute of Educational Sciences. She is working as assistant profesor in Kafkas University Dede Korkut Faculty of Education. 